\title{
CLASSIFICATION OF THE ORCHIDACEAE AND THEIR PROBABLE ORIGIN*
}

\author{
R. L. DRESSLER
}

(Accepted for publication 20.9.1982)

\begin{abstract}
Dressler, R.L. (Smithsonian Tropical Research Institute, Apartado 2072, Balboa, Rep. of Panama) 1983. Classification of the Orchidaceae and their probable origin. Telopea 2(4): 413-424-Though we need much more data, especially on primitive orchids, increased knowledge is leading to a more natural classification. The Apostasioideae and Cypripedioideae, with 2 or 3 fertile anthers, are each amply distinct. The monandrous orchids with erect anther and soft pollen form 2 distinct groups: the Orchidoideae have the anther generally surpassing the rostellum, lack subsidiary cells, and most groups have root-stem tuberoids; while the Spiranthoideae have the rostellum subequal to the anther, often have mesoperigenous subsidiary cells, and lack rootstem tuberoids. The Epidendroideae are the major phyletic group, about $80 \%$ of the family. They often have perigenous subsidiary cells, and members with soft pollen generally have the anther bending downward during development. The vandoid tribes do not show such clear ontogenetic bending, but current research on seed structure suggests that the vandoid level of evolution has arisen independently 3 or 4 times from different epidendroid groups, with much parallelism. Of special interest is the presence of fleshy fruits and hard seed coats in 3 subfamilies. It is suggested that the ancestral Liliiflorae were shrubs or vines with broad, possibly net-veined leaves, with berries and an abscission layer between ovary and perianth. The Asparagaceae and Philesiaceae are suggested as possible living relatives. The following names are published on p.422: tribe Tropidieae (Pfitzer) Dressler, stat. nov.; Stereosandrinae Dressler, subtrib. nov.; subtribe Wullschlaegeliinae (Dressler) Dressler, stat. nov.
\end{abstract}

The Orchidaceae seem to be the largest family of flowering plants, and they include quite remarkable diversity in both vegetative and floral features. In spite of their intrinsic interest, the orchids have been rather neglected by botanists. The few taxonomists who have specialized in orchids have been too swamped by species and genera to give much thought to the overall classification of the family, and other aspects of orchid botany are still quite poorly known. Lacking an adequate classification of the genera into tribes and subfamilies, many intriguing patterns of evolution have been overlooked or obscured. In most cases, the traditional system of Schlechter (1926), for example, named evolutionary levels, rather than phyletic groups (see fig. 1). As must often happen, the straight, uniaxial phyletic tree evolves into a much-branched shrub, as better data become available and our understanding grows.

I presented a short paper on this subject at the Second International Congress on Systematic and Evolutionary Biology, in Vancouver, in 1980. At that same meeting, Dr Wilhelm Barthlott said 'Bob, you should come to Heidelberg again. We have much more data on seed structure now'. Some of these new data call for revision of my ideas on orchid classification (then in press). While further new data will undoubtedly appear, the overall scheme of orchid classification seems to be taking shape. We will here review this classification, and see if it gives us any hints as to the origin of the orchids. The system used here is that given in my recent book (1981), with a couple of important changes and several minor ones (Appendices I-III).

\footnotetext{
* Paper presented at XIII International Botanical Congress, Sydney, 1981. Symposium: Systematics and Evolution of the Liliiflorae Convenors: $\mathrm{H}$. Huber and $\mathrm{Hj}$. Eichler
} 
1. Subfamily Apostasioideae-Neuwiedia and Apostasia form a distinctive and primitive subfamily. Some authors would remove this group from the Orchidaceae, but I do not find the evidence for such removal very convincing. Apostasia, with fertile lateral anthers closely clasping the style, and the median anther sterile or lacking, is quite unlike other orchids, but Neuwiedia provides a fair approximation of an ancestral orchid. All three anthers are fertile, and the perianth is distinctly zygomorphic. It is not clear whether or not the pollen of the apostasioids is sticky, like that of other primitive orchids. The seed of Apostasia has a hard, crustose seed coat, though the fruits are not fleshy. The fruit of Neuwiedia may be either a fleshy berry or a capsule, and the seed has a hard, crustose seed coat in some species.

2. Subfamily Cypripedioideae-The four lady-slipper genera show relatively uniform floral features, with fertile lateral anthers, a median staminode, and a saccate lip with a median entrance and two lateral exits which lead under the stigma and then the anthers. Selenipedium is a tall plant $(1.5$ to $5 \mathrm{~m})$ with relatively small flowers. The aromatic fruits and crustose seed coats are surprisingly like those of Vanilla.

3. Subfamily Spiranthoideae-With this subfamily, we encounter a much larger group with about seventy genera and hundreds of species. In this and the following subfamilies, only the median anther is fertile, with the lateral anthers normally either absent or represented by wing-like staminodes. In the Spiranthoideae the anther is erect and subequal to the rostellum, so that the pollinia are attached to a terminal viscidium. The stomata often have mesoperigenous subsidiary cells (except Tropidieae?), an unusual feature in the Monocotyledonae. This subfamily does not show clear close relationships to any other.

3a. Tribe Tropidieae-Though treated as a subtribe of the Erythrodeae in my earlier treatment, these two tribes are quite distinctive in several features. Preliminary observations indicate that the subsidiary cells of Corymborkis are not mesoperigenous, casting doubt on the close alliance of this group with the Erythrodeae. Both genera have elongate, rather woody stems and clearly plicate leaves. The pollinia of Corymborkis are sectile, but those of Tropidia apparently are not.

3b. Tribe Erythrodeae-This group of herbs is distinguished by sectile pollinia; in most genera the base of the stem is horizontal, but otherwise not sharply differentiated as a rhizome, and the leaves are scattered on the erect portion of the stem.

3c. Tribe Cranichideae-This group has soft or rather hard, but never sectile, pollinia, and the fleshy roots are clustered on a short rhizome. The leaves, too, are closely clustered, forming a rosette.

4. Subfamily Orchidoideae-The Ophrydeae of the traditional classifications, unlike most other groups, was based on a number of correlated features, and was thus clearly more natural than the Polychondreae or the Diandreae, for example. I now treat this complex as the most specialized tribes of a subfamily that also includes the Neottieae and the Diurideae, though this classification will undoubtedly meet a good deal of resistance. Whatever the taxonomic disposition, it seems clear that the Orchideae and Diseae are closely allied to the Diurideae. The Orchidoideae are characterized by the lack of subsidiary cells, by usually having the anther project beyond the rostellum, and in most groups, by the peculiar "root-stem tuberoid".

4a. Tribe Neottieae. This tribe is a relatively small group, rather primitive and best represented in the northern hemisphere. Root-stem tuberoids do not occur in this tribe, and it is not as conclusively tied in to this subfamily as are the Diurideae. Indeed, the closest relationship of the Neottieae might be with the Cypripedioideae, a group with which they agree in habit, large chromosomes and seed structure.

4b. Tribe Diurideae-This remarkable group of terrestrials is primarily Australian, with outliers in Asia and South America. Most members of this tribe 
have root-stem tuberoids. Floral features are quite varied, and most of the features which have been taken as diagnostic of the Orchideae are to be found in different members of this tribe. There are two main complexes, and one might even separate the Diurideae in the strict sense (Diuridinae and Prasophyllinae) from the remainder, for which the name Geoblasteae Barb. Rodr. is available.

4c. Tribe Orchideae-This tribe is well represented in Europe and relatively well studied. The members are characterized by root-stem tuberoids, by having the base of the anther firmly united with the column, by a double viscidium, by sectile pollinia and by having the anther more or less erect (parallel with the axis of the column).

4d. Tribe Diseae-This primarily African group is closely allied to the Orchideae and often included in that tribe. The Diseae differ primarily in having the anther bent back from the axis of the column, in some cases being quite "upside down" as compared to the Orchideae. The nectaries of the Diseae are diverse, but never a single spur at the base of the lip, as is the rule in the Orchideae. The floral structure of some Diseae is remarkably complicated.

5. Subfamily Epidendroideae-With this group, we come to the major orchid group, with by far the greatest taxonomic and morphological diversity. Most Epidendroideae have hard, rather waxy or bony pollinia, but this feature is not diagnostic for the subfamily, as we find every intermediate step between soft, mealy pollinia and hard, bony ones. Many Epidendroideae have perigenous subsidiary cells. Many epidendroid orchids show clear ontogenetic bending of the stamen, so that the anther is erect in early stages and then becomes incumbent, or bent downward at the column apex. I attempted to use this feature to distinguish the epidendroid orchids from the more advanced vandoid orchids, in which such bending is not evident. Unpublished data from Barthlott and Ziegler strongly indicate, however, that the vandoid group is polyphyletic, as we will discuss in more detail below. We may, for convenience, divide the Epidendroideae into evolutionary levels, which, though somewhat arbitrary, still aid in discussion of the group. The Vanilleae and Gastrodieae both have soft, undivided pollinia, and we may characterize them as vanilloid. The Arethuseae, Malaxideae, Dendrobieae and Epidendreae usually have hard pollinia, but lack, for the most part, stipes and these may be referred to as the epidendroid tribes. The remaining tribes (except Cryptarrheneae) are all vandoid, that is, they show both viscidium and stipe associated with the pollinia.

5a. Tribe Triphoreae-A small American group with three genera, this tribe agrees with the Epidendroideae in having perigenous subsidiary cells, but is atypical in having the anther erect or nearly so. In general floral features these genera are comparable with the Neottieae, but do not seem at all closely allied to that tribe. Triphora, with a marked tendency to saprophytism, has what appear to be tuberoid roots. Both Triphora and Psilochilus have conduplicate leaves, while the single, large leaf of Monophyllorchis is distinctly plicate. I do not attempt to put this tribe in my phyletic diagrams, as I am not sure just where it should be placed in relation to the vanilloid tribes.

5b. Tribe Vanilleae-This tribe is characterized by having four relatively soft pollinia. The pollen grains are rather smooth and generally quite thin-walled, thus very reminiscent of the Cypripedioideae. The Vanillinae and Palmorchidinae include very primitive genera, and we will look at them in greater detail when we try to extrapolate to the ancestral orchids.

5c. Tribe Gastrodieae-These are all saprophytes, except for Nervilia, and are characterized by sectile pollinia. I had treated Wullschlaegelieae and Epipogieae as separate tribes, but they fit fairly well here, and their inclusion here may give somewhat better perspective. In this tribe we first encounter thickened corms. Corms and pseudobulbs are frequent features of the more advanced Epidendroideae.

5d. Tribe Arethuseae-This tribe is characterized by moderately soft to moderately hard pollinia and plicate leaves. Each anther locule is divided, so that 
eight pollinia are formed in nearly all genera. Arethusa has somewhat sectile pollinia, suggesting a relationship to the Gastrodieae.

5e. Tribe Epidendreae - This tribe includes three Old World subtribes and three New World subtribes with (almost always) conduplicate leaves. The Old World genera usually have eight pollinia, while the New World genera show a reduction series from eight to two.

5f. Tribe Malaxideae-This tribe is characterized by four or two naked pollinia. The leaves may be either plicate or conduplicate, and the flowers have little or no column foot.

5g. Tribe Dendrobieae-The relationship (or lack of same) between Dendrobium and Eria is a problem with which I have struggled repeatedly. In the structure of the pollinia, they are very different, yet habit, chromosome number and general flower form are much the same, and many authors have considered them to be very closely allied. In my recent book, I placed both subtribes, and many others, in the Epidendreae, but without feeling very happy about the arrangement. Now, Barthlott and Ziegler assure me that the Thuniinae, Coelogyninae, Glomerinae, Dendrobiinae and Bulbophyllinae all share very similar seed structure that is quite unlike that of Eria (which remains in the Epidendreae). Placing them together as the tribe Dendrobieae seems to form a very natural tribe. Published descriptions of Thunia do not agree on whether there are eight or four pollinia. Otherwise, the whole tribe may be characterized by either four or two pollinia, and, when four, they are laterally flattened, rather than clavate.

5h. Tribe Cryptarrheneae-The relationships of this tiny tribe are not at all clear. Though superficially vandoid, the pollinia are actually attached to the viscidium by large caudicles, rather than a stipe. For now, the borderline between the epidendroid and vandoid complexes seems appropriate for the Cryptarrheneae.

5i. Tribe Calypsoeae-I had thought Calypso not to be truly vandoid, because of its clearly incumbent anther. With the new evidence that the shift from epidendroid to vandoid has occurred several times, this seems less important. Seed structure shows that the Corallorhizinae were misplaced in the Maxillarieae, and their seed structure seems compatible with that of the Calypsoinae, so that I have placed them together for now. All have four pollinia and plicate leaves.

5j. Tribe Cymbidieae-Seed structure indicates that this is a natural and distinctive group, characterized by plicate leaves, pseudobulbs or corms of several internodes, and two, notched pollinia. Seed structure also supports the separation of the Eulophia complex and Dipodium from the Cyrtopodiinae (As the Eulophiinae).

5k. Tribe Polystachyeae-A largely Old World group with conduplicate leaves, terminal inflorescence and four pollinia; seed structure supports a close relationship to the following tribe.

51. Tribe Vandeae-This is the major Old World group of vandoid orchids, with uniformly monopodial growth habit and four or two pollinia.

$5 \mathrm{~m}$. Tribe Maxillarieae-A New World group with four pollinia.

5n. Tribe Gongoreae-A New World group characterized by plicate leaves and two pollinia, some genera have very complex flower structure; all are pollinated by perfume-gathering male euglossine bees.

5o. Tribe Oncidieae-A major New World group characterized by conduplicate leaves and two pollinia. 


\section{The polyphyletic origin of the vandoid orchids}

The vandoid orchids have been variously characterized as a taxonomic group (Bentham, 1881; Brieger, 1970-1976) or as an evolutionary level (Dressler, 1974). While I advocated subfamily status in my recent book (1981), I had second thoughts before the book was in print. Many features have been taken to characterize the vandoid orchids: lateral inflorescence, a lack of obvious bending in anther development, reduced anther partitions, superposed pollinia, viscidia, stipe, etc., but no two of these features are perfectly correlated. This, in itself, of course, does not prove that the group is unnatural, but it does impose problems in the definition and circumscription of the group. The most commonly accepted criterion for the vandoid group is the presence of a stipe, or strap of tissue, attaching the pollinia to the viscidium, but such a structure is quite clearly polyphyletic. The data on seed structure, from Barthlott and Ziegler, show rather clearly that the vandoid orchids are polyphyletic by any definition. With reference to seed structure, they find three main groups of vandoid orchids.

1. The Vandeae and Polystachyeae. I had suggested a close relationship between these two tribes, but quite without any supporting evidence. Barthlott and Ziegler report that their seed structure is similar and indicates their derivation from the Dendrobieae.

2.Maxillarieae, Gongoreae and Oncidieae. These exclusively American tribes are each distinctive, but Barthlott and Ziegler indicate that they share a close common ancestry with the Epidendreae.

3. The Cymbidieae. This is a distinctive group not closely related to either of the above groups. They are moderately well represented in both hemispheres. I have tentatively placed the Calypsoeae near the Cymbidieae in my phyletic diagrams, but this may require revision when the seed structure is more fully reported.

In addition to these three (or possibly four) major vandoid groups, we find well developed stipes in Sunipia and some species of Bulbophyllinae and in Appendicula. I had dismissed reports of stipes in the Podochilinae as referring to modified pollinia, but I quite overlooked Seidenfaden's excellent drawing of Appendicula floribunda (Seidenfaden, 1975). While the presence of six clavate pollinia would be very anomalous in the strictly vandoid tribes, there is little doubt that $A$. floribunda (like its close allies) has definite stipes.

I conclude, then, that stipes have evolved at least five times within the Epidendroideae, and possibly more often. A corollary of this is that the developmental differences I had thought important in distinguishing the epidendroid and vandoid groups have also evolved in a parallel fashion, and the majority of the vandoid orchids presumably do have the anther incumbent at a very early stage, as originally suggested by Hirmer (1920).

It is a source of minor embarrassment to me that every time I review orchid classification, the epidendroid and vanilloid tribes seem to shrink in number, while the vandoid tribes multiply. Yet, under the present classification the tribes seem to be both natural and definable on all levels. I cannot see any change that would maintain the present degree of definability. This relationship is paralleled to some degree by the generic diversity of the two levels. There are more than twice as many species in the epidendroid tribes than in the vandoid tribes, yet the vandoid genera outnumber the epidendroid genera by about eighty per cent.

\section{Orchids with naked pollinia}

In strong contrast to the structural complexity of the vandoid orchids, we find hard and quite naked, or unadorned, pollinia in the Dendrobiinae, and most Bulbophyllinae and Malaxideae. In the Dendrobiinae and Bulbophyllinae, successful 
pollination depends on a very exact mechanism that deposits the pollinia on the surface of any object that brushes the rostellum and the anther in just the right way. If the anther be lifted up by a pin, the pollinia fall out and are lost. As far as I know, the pollinia of the Dendrobiinae are always quite naked, and no viscidium is ever present. In some Bulbophyllinae, even though caudicles are quite lacking, there are definite viscidia that are attached to the pollinia during ontogeny. Thus, if a pollinator touches the viscidium, the attached pollinia are removed with it. In some Bulbophyllum species, and in Monomeria and Sunipia, the next evolutionary step has occurred, and there is a definite stipe between the viscidium and the pollinia. This stipe is usually rather thick, but seems quite homologous with the stipes of other groups. In the Malaxideae the pollinia are usually quite narrow at the rostellar end, and there frequently seem to be microscopic viscidia (usually two), but I know of no stipes in the Malaxideae.

Naked pollinia seem to impose definite functional limitations on the structure of the flower and especially of the column. Thus, these groups with naked pollinia are each relatively uniform in flower structure, except where the evolution of viscidium or stipe has released the group from such limitations. At the same time, orchid classification is traditionally based on the pollinia and associated structures. When there are no associated structures, there are very few traditional taxonomic features on which to recognize genera. Thus, Bulbophyllum (approx. 1000 species). Dendrobium (1400), Liparis (250), Malaxis (300) and Oberonia (330) are all rather large genera. In biosystematic terms, I am sure that some of the sections of Dendrobium are better "genera", than many of the traditional genera of the Vandeae or the Maxillarieae. At the same time, one must admit that these groups with naked pollinia have been remarkably prolific in the evolution of species. Why this should be, I do not know.

\section{Basic trends in orchid phylogeny}

Rolfe (1909-1912) long ago discussed the evolution of the orchids and gave us a fairly clear idea of some primitive features within the family. We would expect the early orchids to be sympodial plants with fleshy roots, elongate stems, spiral, plicate leaves and a terminal inflorescence. The primitive orchid flower would have erect anther or anthers and soft, sticky pollen. We may suggest that the initial selection for bilateral symmetry involved pollination by Hymenoptera (whether wasps or bees) and that the three ventral (adaxial) anthers were lost very early in orchid evolution. For the Cypripedioideae we may suggest an ancestral stage in which the lip was deeply concave and all three fertile anthers were placed near the edge of the saccate lip (fig. 3). In this group, then, selection favoured keeping both lateral anthers, and the median anther became a sterile shield. In the ancestral Spiranthoideae, the anther and the stigma must have been subequal in length, so that a terminal rostellum and viscidium evolved. In the Orchidoideae, on the other hand, the anther projected beyond the stigma, and the rostellum evolved in relationship to be basal part of the anther. In the ancestral Epidendroideae the anther and stigma bent downward toward the lip, thus increasing the probability that a retreating pollinator would touch the stigma first and then tip back the anther and touch the pollen mass. These, I suggest, were the initial steps which led to the subfamilies as we now know them. Given the features of the primitive orchids, in which the anther was borne above the stigma and the pollen mass was somewhat sticky, the function of stigmatic fluid to stick the pollen mass to the pollinator, the evolution of rostellum, viscidium and finally the stipe were logical developments from this basic flower structure. Viewed in this light, the parallelism that is so prevalent in orchid evolution becomes a bit less mysterious.

\section{Features associated with primitive orchids}

We have already outlined the general features of primitive orchids. Now, let us consider other details which we find associated with one or more groups of primitive orchids. 
1. Net-veined leaves. Among the primitive orchid groups, we find net-veined leaves only in Epistephium and Clematepistephium, of the Vanilleae. These two genera, then, are reminiscent of Smilax in aspect. Eriaxis is probably more closely allied to Clematepistephium than is Epistephium, and its leaves are very thick and fleshy. I do not know what sort of venation is hidden within those fleshy leaves.

2. Climbing habit. Vines, too, are found only within the Vanilleae, where Vanilla, Galeola section Galeola and Clematepistephium are climbers.

3. Three-locular ovary. This feature, long recognized as a primitive characteristic within the family, is found in Neuwiedia and Apostasia (Apostasioideae), Selenipedium and Phragmipedium (Cypripedioideae), and Eriaxis, Clematepistephium, Lecanorchis and Palmorchis (Epidendroideae). Other cases may appear, as this feature is easily overlooked.

4. Crustose seed coat. This feature is found in Apostasia and some species of Neuwiedia (Apostasioideae), Selenipedium (Cypripedioideae), Galeola section Cyrtosia, Vanilla and Palmorchis (Epidendroideae). The remaining Vanillinae have winged seeds. Barthlott (1976) interprets the seed of Vanilla is a reduction from a winged seed, as in Epistephium, but the similarity of the seeds of Apostasia and Selenipedium to that of Vanilla suggest rather that the winged seed is an innovation that has arisen only in the Vanillinae.

5. Fleshy fruit. The vast majority of orchid fruits are capsular, but we find fleshy fruit associated with the crustose seed coat mentioned above, except in Apostasia, which apparently has a sticky seed. In Neuwiedia zollingeri (and perhaps in other species), Palmorchis and perhaps in Galeola section Cyrtosia, the pericarp is fleshy, and the fruit seems truly to be a berry. In Vanilla and Selenipedium, however, the pericarp is somewhat thin or leathery (in those species that I have seen), and the seeds are surrounded by fleshy funicles. In all these cases, it is likely that the seeds are dispersed by birds or other animals, but we have no knowledge of natural seed dispersal in these orchids. The relationship between the Vanilleae and the Cypripedioideae is emphasized by the fact that the fruit of Selenipedium, like that of Vanilla, has the aroma of vanillin and has been used for flavouring, both in Panama and in Amazonian Brazil. While I believe the primitive orchid fruit to have been fleshy, it was probably elongate, as in Vanilla or Selenipedium. Even in primitive orchids with capsular fruit, the fruit is usually narrow and elongate.

6. Abscission layer below perianth. We find an abscission layer between the ovary and the perianth (and column) in Phragmipedium and Paphiopedilum (Cypripedioideae), apparently in Neuwiedia veratrifolia (Apostasioideae; to judge from Botanical Magazine plate 7368), in all Vanillinae, and in Pogoniinae and Lecanorchis (Epidendroideae). If the flower is not pollinated, it falls from the pedicel and ovary promptly. If pollinated, it may persist for much longer, but eventually it falls from the apex of the developing fruit. This feature is rarely mentioned by taxonomists, and it may well appear in other orchid groups that I have not mentioned.

7. Calyculus. In Epistephium and Lecanorchis (Epidendroideae) we find a threelobed cupule at the base of the perianth. This calyculus remains with the ovary when the flower falls off. I know nothing of its function or morphological significance.

\section{What, then, was the $U r$-orchid?}

Features that we find associated with a single group of primitive orchids may or may not have been present in the early stages of orchid evolution. Thus, we should not discount the possibility that the ancestral orchids were vines, or had net-veined leaves or a calyculus beneath the perianth, but these three features are found only in the Vanilleae today, and we cannot be sure whether they are ancestral features or innovations found only in the Vanilleae. On the other hand, features that are found in the otherwise rather diverse Apostasioideae, Cypripedioideae and the primitive 
Epidendroideae are very likely to be features inherited from some remote common ancestor. I suggest, then, that the early orchids had a fleshy, three-locular fruit with hard, crustose seed coat (black or brown), and an abscission layer between the ovary and the perianth. I have suggested that the primitive habit was sympodial with spiral, plicate leaves. Such a habit occurs in primitive members of each subfamily. It is interesting to compare the habit of Palmorchis with that of Selenipedium (which, however, has distichous leaves). Such a habit, with a bracteate inflorescence that produces relatively small flowers one by one over a long period, might well be the primitive habit for the family. Of course, there may not have been a sharply defined inflorescence. The basal flowers may have been borne in the axils of leaves that graded upwards into bracts. Such a habit could well have been associated with the first development of resupination. I visualize a flower held more or less horizontally that twisted away from its subtending foliaceous bract. Once the flower became dorsiventral, selection would favour resupination, but the flower must have been resupinate while the dorsiventrality evolved, else one would expect the abaxial anthers to be lost rather than the reverse.

In our attempt to pin down the relationships of the Orchidaceae, I am hindered by two kinds of ignorance. 1) The primitive orchids are, for the most part, the hardest to cultivate, and except for Vanilla, we lack detailed information on their anatomy, biochemistry, cytology, etc. 2) I, personally, do not know enough about the other Liliiflorae, and I could not find the details that I need in Panama (i.e., before the presentation of this paper at the Botanical Congress). Still, the features that I have outlined above suggest to me that the ancestor of the orchids should be sought, not in the Liliales (of Huber, 1969), but rather in the Asparagales. The dust seeds that characterize most orchids seem quite out of place in the asparagoid line, but the seeds of the most primitive orchids seem to fit the Asparagales a good deal better, and the habit, the fleshy fruit, and especially the abscission layer at the base of the perianth, fit the Asparagales much better than the Liliales. Huber assigns the Hypoxidaceae to the Asparagales, but the traditional comparison of the Apostasioideae with Curculigo seems to be based on superficial resemblance, rather than any demonstrably close relationship. I would seek the closest alliance of the Orchidaceae rather in the Asparagaceae family group, but I cannot point to any one family as a group that seems especially appropriate. With more knowledge of both the Asparagales and the primitive orchids, we might possibly pick out one family as "closest living relative", but it is equally likely that the asparagoid ancestor of the orchids evolved into orchids and left no other descendants in the modern flora.

\section{REFERENCES}

Barthlott, W. (1976). Morphologie der Samen von Orchideen im Hinblick auf taxonomische und funktionelle Aspekte. Proc. 8th World Orchid Conf., 444-453.

Bentham, G. (1881). Notes on Orchideae. J. Linn. Soc. Bot. 18: 281-360.

Brieger, F.G. (1970-1976). Many taxonomic treatments in "R. Schlechter," Die Orchideen, 3rd edn, ed. F.G. Brieger, R. Maatsch, \& K. Senghas. (Berlin: Paul Parey.)

Dressler, R.L. (1974). Classification of the orchid family. Proc. 7th World Orchid Conf., 534-537.

Dressler, R.L. (1981). 'The Orchids: Natural History and Classification.' (Cambridge: Harvard University Press.)

Hirmer, M. (1920). Beiträge zur Organographie der Orchideenblüte. Flora 13: 213-309.

Huber, H. (1969). Die Samenmerkmale und Verwandschaftsverhältnisse der Liliifloren. Mitt. Bot. Staatssamml. München 7: 219-538.

Huber, H. (1977). The treatment of the monocotyledons in an evolutionary system of classification. Plant Systematics and Evolution, Supplement 1: 284-298.

Rasmussen, F.N., \& H. Rasmussen (1979). Notes on the morphology and taxonomy of Diceratostele gabonensis (Orchidaceae). Bull. Jard. Bot. Nat. Belg. 49: 139-148. 
Rolfe, R.A. (1909-1912). The evolution of the Orchidaceae. Orchid Rev. 17-20: (in parts).

Schlechter, R. (1926). Das System der Orchidaceen. Notizbl. Bot. Gart. Mus. BerlinDahlem 9: 563-591.

Seidenfaden, G. (1975). Contributions to the orchid flora of Thailand 6. Bot. Tidsskr. 70(1): $64-97$.

APPENDIX I. Orchid classification, as I see it, at this moment.

\begin{tabular}{|c|c|}
\hline Apostasioideae & Epidendroideae contd \\
\hline Cypripedioideae & Arethuseae \\
\hline \multirow{10}{*}{$\begin{array}{l}\text { Spiranthoideae } \\
\text { Tropidieae } \\
\text { Erythrodeae } \\
\text { Cranichideae } \\
\text { Spiranthinae } \\
\text { Pachyplectroninae } \\
\text { Manniellinae } \\
\text { Cranichidinae } \\
\text { Cryptostylidinae }\end{array}$} & Arethusinae \\
\hline & Bletiinae \\
\hline & Sobraliinae \\
\hline & Epidendreae \\
\hline & Eriinae \\
\hline & Podochilinae \\
\hline & Thelasiinae \\
\hline & Laeliinae \\
\hline & Meiracyllinae \\
\hline & Pleurothallidinae \\
\hline \multicolumn{2}{|l|}{ Orchidoideae } \\
\hline \multirow{3}{*}{$\begin{array}{l}\text { Neottieae } \\
\text { Limodorinae } \\
\text { Listerinae }\end{array}$} & Malaxideae \\
\hline & Dendrobieae \\
\hline & Thuniinae \\
\hline Diurideae & Coelogyninae \\
\hline $\begin{array}{l}\text { Chloraeinae } \\
\text { Caladeniinae }\end{array}$ & Adrorhizinae \\
\hline $\begin{array}{l}\text { Caladeniinae } \\
\text { Pterostylidinae }\end{array}$ & $\begin{array}{l}\text { Glomerinae } \\
\text { Dendrobiinge }\end{array}$ \\
\hline $\begin{array}{l}\text { Pterostylidinae } \\
\text { Acianthinae }\end{array}$ & $\begin{array}{l}\text { Dendrobiinae } \\
\text { Bulbophyllinae }\end{array}$ \\
\hline Aclanthinae & Sunipiinae \\
\hline Diuridinae & Cryptarrheneae \\
\hline Prasophyllinae & Calypsoeae \\
\hline \multirow{4}{*}{$\begin{array}{l}\text { Orchideae } \\
\text { Orchidinae } \\
\text { Habenariinae } \\
\text { Huttonaeinae }\end{array}$} & Corallorhizinae \\
\hline & \\
\hline & Cymbidieae \\
\hline & Eulophiinae \\
\hline \multirow{4}{*}{$\begin{array}{l}\text { Diseae } \\
\text { Disinae } \\
\text { Satyriinae } \\
\text { Coryciinae }\end{array}$} & Cyrtopodiinae \\
\hline & Genyorchidinae \\
\hline & $\begin{array}{l}\text { Acriopsidinae } \\
\text { Catasetinge }\end{array}$ \\
\hline & $\begin{array}{r}\text { Catasetinae } \\
\text { Polystachyeae }\end{array}$ \\
\hline Epidendroideae & $\begin{array}{l}\text { Polystachyeae } \\
\text { Vandeae }\end{array}$ \\
\hline Triphoreae & $\begin{array}{l}\text { Vandeae } \\
\text { Sarcanthinae }\end{array}$ \\
\hline \multirow{2}{*}{$\begin{array}{l}\text { Vanilleae } \\
\text { Vanillinae }\end{array}$} & $\begin{array}{l}\text { Sarcanthinae } \\
\text { Angraecinae }\end{array}$ \\
\hline & Aerangidinae \\
\hline Lecanorchidinae & Maxillarieae \\
\hline Palmorchidinae & Zygopetalinae \\
\hline Pogoniinae & Bifrenariinae \\
\hline Gastrodieae & $\begin{array}{l}\text { Lycastinae } \\
\text { Maxillariinae }\end{array}$ \\
\hline Nerviliinae & Dichaeinae \\
\hline $\begin{array}{l}\text { Gastrodiinae } \\
\text { Rhizanthellinae }\end{array}$ & Telipogoninae \\
\hline Epipogiinae & Ornithocephalinae \\
\hline Stereosandrinae & Gongoreae \\
\hline Wullschlaegeliinae & Oncidieae \\
\hline & Pachyphyllinae \\
\hline
\end{tabular}


APPENDIX II. Problem groups in orchid classification. Here I will briefly discuss or list some of the groups that may come up in future revisions of orchid classification.

Diceratostele-I had followed Summerhayes in associating this African genus with Palmorchis. Now that I have seen the study by Rasmussen and Rasmussen (1979), I feel sure that Diceratostele is not closely allied to Palmorchis. It may be allied to the Tropidieae, but we need to know more about seed and pollen.

Thecostelinae-The genus Thecostele has been associated with Acriopsis, in the Cymbidieae. I have removed Acriopsis to a separate subtribe, but I still kept Thecostele in the Cymbidieae, thinking that there might be a relationship with Porphyroglottis. Now that I have Thecostele flowering in my own garden, I strongly suspect that it will prove to be another "vandoid" derivative of the Bulbophyllinae, but I will reserve judgement until seeds become available.

There are several other genera or complexes which might merit subtribal status; these are listed herewith with brief comment.

Arpophyllum (Sobraliinae)-very distinct in habit, though florally much like Elleanthus.

Bartholina and Holothrix (Orchidinae)-quite distinctive.

Bromheadia (Cyrtopodiinae)-distinctive in habit; might even be closer to the Polystachyeae.

Chysis (Bletiinae)-distinctive in habit and form of pollinia.

Coelia (Bletiinae)--seed structure suggests that it is a misfit in the Arethuseae.

Claderia (Cyrtopodiinae)-may belong with the Eulophiinae

Govenia (Corallorhizinae)-quite distinctive and geographically anomalous.

Prescottia alliance (Cranichidinae)-may well merit a separate subtribe.

APPENDIX III. Name changes. The revisions of orchid classification called for by newer data require a few names that have not been validly published. These names are validated herewith.

1. Tribe Tropidieae (Pfitzer) Dressler, stat. nov,_-subtribe Tropidiinae Pfitzer, Entw. Nat. Anord. Orch. 99. 1887. Type: Tropidia Blume.

2. Stereosandrinae Dressler, subtrib. nov. plantis saprophyticis, tenuibus; labello integro, bicalloso; anthera sublibera, erecta, columna longiora; polliniis sectilibus, caudiculatis. Type: Stereosandra Blume.

Subtribal status has been suggested for this anomalous genus already by Brieger (1975), but the subtribal name has not been validly published.

3. Subtribe Wullschlaegeliinae (Dressler) Dressler, stat. nov.-tribe Wullschlaegelieae Dressler, Orquidea (Méx.) 7: 278. 1980. Type: Wullschlaegelia Reichb. f.

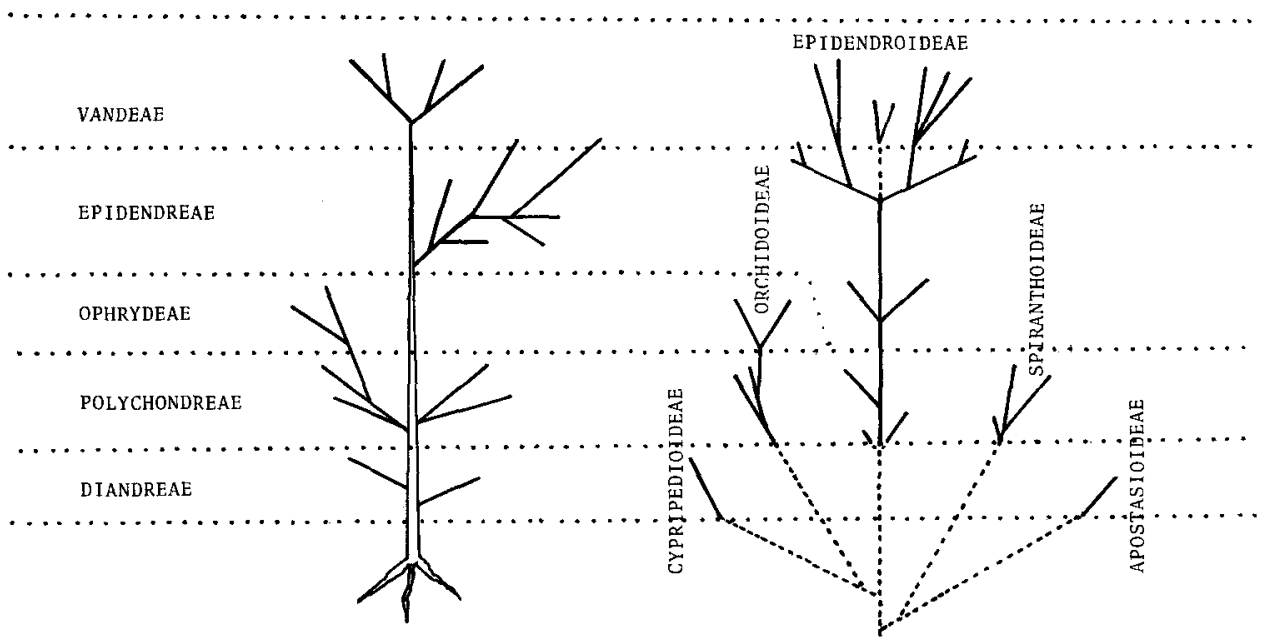

Figure 1. A comparison of the traditional orchid classification (left) and a current classification into five subfamilies (right). In the traditional system, two or more phyletic lines may be combined in a single taxon, or a part of a natural phyletic group may be treated as an isolated taxon, as in the Ophrydeae. 

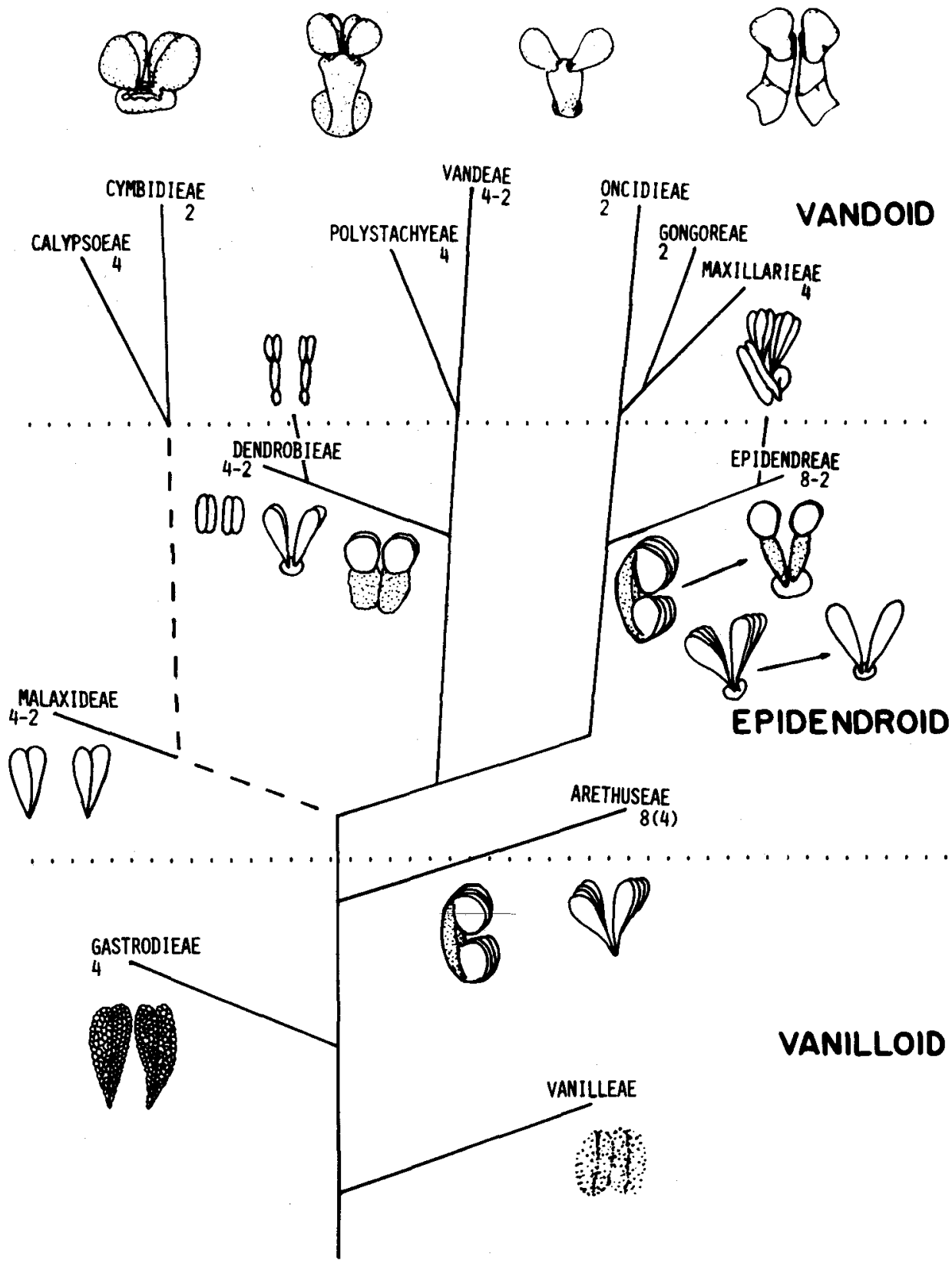

Figure 2. A tentative scheme of relationships for the subfamily Epidendroideae. The Epidendreae/Arethuseae clearly have 8 pollinia as the primitive condition, while the Malaxideae/Dendrobieae may not have passed through such a stage. The vandoid level of evolution has been reached by a few members of the Dendrobieae and Epidendreae, and the bulk of the vandoid tribes represent at least three lines of evolution: the Polystachyeae/Vandeae, that share a close common ancestry with the Dendrobieae; the exclusively American Oncidieae, Gongoreae and Maxillarieae, that share a close common ancestry with the Epidendreae; and the Calypsoeae/Cymbidieae, that are not closely allied to either of the other main groups. 


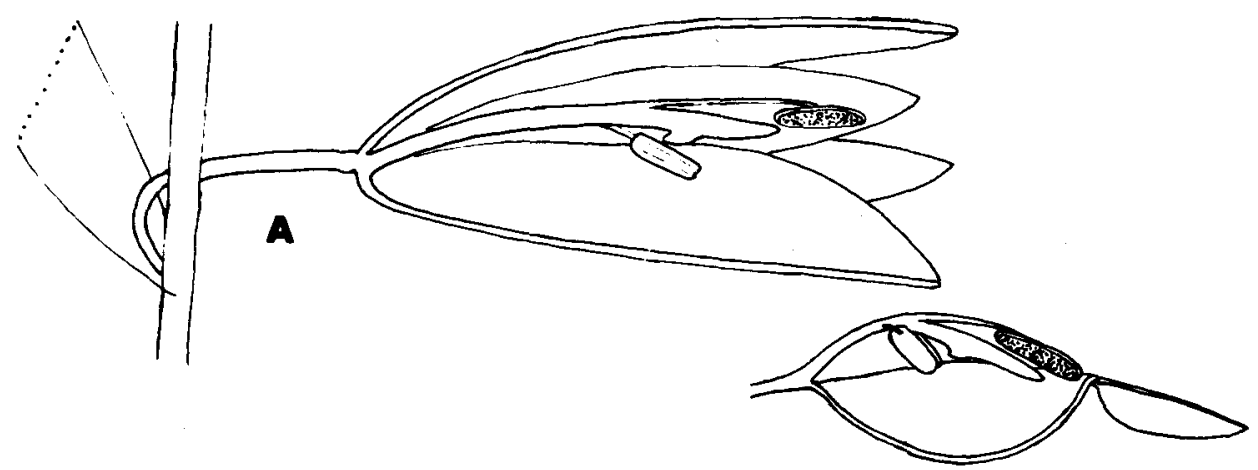

Cypripedioideae
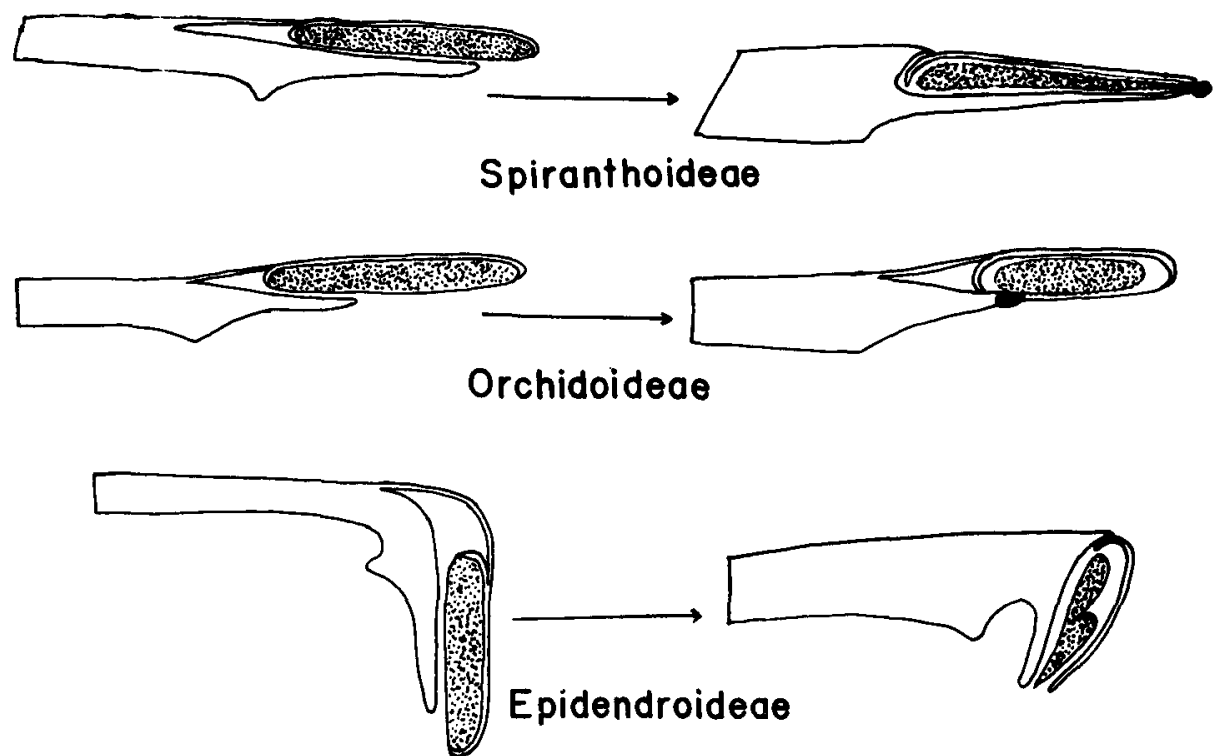

Figure 3. A longitudinal section of an hypothetical primitive orchid flower. The other drawings represent early stages in the differentiation of their respective subfamilies. 